\title{
Yoav Kapshuk* \\ Conceptual Ambiguity in Coding the Categories of Peace Agreement and Peace Process
}

https://doi.org/10.1515/peps-2020-0003

Received January 20, 2020; accepted November 22, 2020

\begin{abstract}
Within the field of peace and conflict studies, data-production on peace agreements has rapidly increased. One complicated task for scholars and practitioners alike is understanding the relationships between peace agreements and the relationships between agreements and processes. For example, discerning when an agreement establishes continuity with previous agreements and, thus, belongs to the same peace process or when an agreement signals the start of a new peace process is not straightforward. In this study, I highlight what appears to be a fuzzy boundary for categorizing some disciplinary core concepts which, in turn, can cause our data to be unreliable. As a point of comparison, I investigate how two major peace agreement datasets UCDP Peace Agreement Dataset and PA-X Peace Agreement Dataset - associate peace agreements with peace processes and find differences and ambiguities with respect to how they are coded in both databases. As a result of such inconsistencies, analyses drawn from these data can have different outputs and lead to misunderstandings about peace processes. Here, I demonstrate the disciplinary need for clearer principles to effectively associate peace agreements with peace processes and then argue for developing a disciplinary standard for the criteria used to operationalize peace processes. Crucially, a standard method for aggregating agreements into processes will facilitate consistent data production across databases.
\end{abstract}

Keywords: UCDP PA-D, PA-X, data, peace agreement, peace process, coding

\footnotetext{
*Corresponding author: Yoav Kapshuk, Kinneret College on the Sea of Galilee, Tzemach, 15132, Israel, E-mail: kapshuk@gmail.com. https://orcid.org/0000-0002-9737-4468
} 


\section{Introduction}

In December 2015 representatives of the Colombian government and the FARC guerrillas reached the 'Agreement on the victims of conflict', ${ }^{1}$ a partial (interim) agreement that related to other agreements also signed during the peace process in Colombia (BBC 2016). In the field of data-production, understanding when an agreement has continuity with previous agreements and when an agreement initiates a new peace process is a complex task, as I will show through an examination of two major peace agreement datasets. For example, PA-X Peace Agreement Dataset (Bell et al. 2020) associates the Colombian 'agreement on the victims of conflict' with a peace process (\#101) that also contains the 2016 'final agreement for ending the conflict and building a stable and lasting peace', a comprehensive agreement based on all previous partial agreements between the FARC and the government. In contrast, UCDP (Uppsala Conflict Data Program) Peace Agreement Dataset (Pettersson, Högbladh, and Öberg 2019) associates the 'agreement on the victims of conflict' with a peace process (\#111) that contains two more partial agreements but not the 2016 'final agreement for ending the conflict and building a stable and lasting peace,' which is associated with another peace process (\#112). This kind of difference is due to a lack of cohesion between the categories of peace agreement and peace process (see Appendix I for a comparison of all peace agreements, and how UCDP PA-D, and PA-X datasets sort them into peace processes).

In this study I question the disciplinary practice of coding individual peace agreements as belonging with particular peace processes. How and according to what agreed upon principles do we create the categories (e.g. conflict, process, agreement) to which we then assign items? And, if there is no disciplinary standard, can we claim that our data are reliable? In my investigation of how two major peace agreement datasets associate peace agreements with peace processes, I found differences between and inconsistencies within these two datasets. Such variation, I argue, is the outcome of creating coding schema for categories with inherently fuzzy boundaries. To this end, an agreement might logically be coded as belonging in one process but could, likewise, be argued that it also belongs in another.

In a given conflict, there are several kinds of agreements that make up a peace process: pre-negotiation agreements deal with the issues to be included in the agenda; partial or interim agreements, sometimes as framework agreements or 'intention agreements', form the basis for dealing with core conflict issues; and final status, full or comprehensive agreements, also called 'resolution

1 Agreement on the Victims of Conflict, Comprehensive System for Truth, Justice, Reparation and Non-repetition, including the Special Jurisdiction for Peace; and Commitment on Human Rights. 
agreements', deal with the core issues and signing these indicates that the parties have resolved all major contested issues and peace can follow (Bell 2003, pp. 44-47; Cox 2019, p. 469). However, in quantitative studies, peace agreements tend to be treated as monolith and few studies objectively examine the operation of data aggregation that associates peace agreements with peace processes. An exception is Ramzi Badran's (Badran 2014) research that uses UCDP PA-D version II (Högbladh 2012) to calculate the rate of provisions in peace agreements. According to Bardan, a peace agreement is "a connected sequence of pacts rather than an isolated deal," and a peace process is the overall contract that emerges gradually from associating all agreements together. Therefore, a "series of interrelated accords within the same peace process are considered one peace agreement ... regardless of the duration of the peace process, as long as the final act in the peace process confirms these accords and puts them into effect” (p. 194). Another study that does not refer to peace agreements as isolated events is Louise Malinder's Amnesty, Conflict and Peace Agreement dataset, which views amnesties as a process rather than an event. Malinder examines the timing of amnesties during the peace process, including the following stages: pre-negotiation, mid-negotiation, comprehensive agreement, and post-agreement (Mallinder 2018). However, as I will show, the duration and stages of peace processes vary from database to database and inconsistencies in the operationalization of coding is also present in both datasets. Thus, had Bardan relied on the PA-X instead of the UCDP PA-D, or had Malinder relied on UCDP PA-D instead of PA-X, their results would be different.

Besides these studies, Fontana et al. introduce 'The Political Agreements in Internal Conflicts Database' and argue that, among other things, the dataset would allow us "to investigate peace processes as a series of agreements and to understand better the relationship between agreements" (Fontana et al. 2020). However, no further details, such as access to the dataset, are yet provided. There are also studies that examine questions of measurement of armed conflict. For instance, in the book 'Building and Using Datasets on Armed Conflicts', several papers deal with measures and definitions of armed conflicts and the reliability of conflict datasets (Kauffmann 2008). In another recent study the authors focus on two concepts for measurement of armed conflicts: aggregation and continuity, including the difficulties of coding the start and end of a civil war (Sambanis and Schulhofer-Wohl 2019). Studies that examine questions of measurement tend to focus on indicators of peace and how to measure them (Guelke 2014; McCartney and Nolan 2014), but none analyzes the lack of coherence between coding for the categories of peace agreement and peace process. This article aims to fill this gap.

The differences between and inconsistencies within these two major databases, UCDP PA-D and PA-X will potentially cause unreliable analyses resulting in 
different data. Associating the same agreements with different processes in the two datasets has substantive implications for scholarship on peace processes because any attempts to draw conclusions about the relationships between agreements in a peace process would differ. For example, what different conclusions can one draw from the example above, in which PA-X associates the 'agreement on victims of conflict' with a process that ends in a comprehensive agreement and the UCDP PA-D associates it with a process that does not end in a comprehensive agreement? Scholarship and predictive knowledge gleaned about the relationship of continuity between different peace agreements reached during a peace process would be different depending on the dataset. When relying on PA-X, one could argue for a positive relationship between dealing with the issue of victims of conflict and signing the comprehensive agreement, while data from UCDP PA-D indicates a negative relationship.

The structure of the article and argument are as follows. First I present differences in defining peace agreements and processes and in sorting agreements to processes in each dataset. Next, I show that in both datasets the categories of peace agreement and peace process have fuzzy boundaries, which results in inconsistencies in how the databases aggregate agreements with processes. Then, I demonstrate how each dataset results in different rates of elements included in any given peace process. For this purpose, I focus on truth and reconciliation, two negotiated provisions that have long-term significance beyond a single signed agreement and are, therefore, suitable to be examined throughout a peace process. As a result of such differences and inconsistencies, I then argue for developing a disciplinary standard for the criteria used to operationalize peace processes and for aggregating agreements to processes which, in turn, will facilitate consistent data production across databases. Establishing clear criteria may lead researchers to build a new dataset where peace processes are the primary unit of analysis.

\section{Differences Between UCDP PA-D and PA-X Datasets}

The latest version of the UCDP Peace Agreement Dataset, version 19.1, includes all peace agreements between warring parties active in the UCDP data, from the period of 1975-2018 (Pettersson, Högbladh, and Öberg 2019). In all, the dataset covers 355 peace agreements, found in 34\% of all conflicts recorded in the UCDP Armed Conflict Dataset, version 19.1, during the time period. According to the UCDP definition, a state-based armed-conflict involves violence between states or 
violence between a state government and a rebel group during which the use of armed force between two parties results in at least 25 battle-related deaths in a year (Pettersson, Högbladh, and Öberg 2019, p. 581). According to UCDP, "peace agreements address the incompatibility, or conflict issue, stated by the warring parties, by either settling all or part of it, or by clearly outlining a process for how to regulate it". A peace process is defined as "a formal process in which the warring parties either have decided to settle the incompatibility in a process in which one issue at the time is regulated by an agreement, or where an agreement that builds on a previous peace agreement is signed" (Harbom, Hogbladh, and Wallensteen 2006, p. 623-624). By this definition, a peace process can include as few as one to any number of agreements. The dataset also includes a variable named 'frame' that examines 'when in the peace process was the peace agreement signed': [1] in a process and not as the final agreement in the ongoing process; [2] as a final agreement ending a peace process or outside a peace process as a single agreement; [3] an agreement that reaffirmed a final peace agreement (Högbladh 2019, p. 9).

PA-X v.3 of the Political Settlement Research Program at the University of Edinburgh contains 1832 peace agreements from 1990 through 2019 (Bell et al. 2020). According to PA-X, a conflict is defined as "armed or military violence, causing more than 25 conflict-related deaths in one year," and peace agreements are defined as "formal, publicly available documents, produced after discussion with conflict protagonists and mutually agreed to by some or all of them, addressing conflict with a view to ending it." PA-X contains far more documents defined as peace agreements than the UCDP PA-D because the PA-X definition of a peace agreement is broader. Peace agreements according to PA-X “... often avoid or redefine the incompatibility stated by the main armed actors, to address deeper root causes which precipitated the onset of armed conflict" (Bell and Badanjak 2019, p. 453). According to PA-X a peace process is also called a "transition process". A peace or transition process is defined as "a formal attempt to bring political and/or military protagonists of conflict to some sort of mutual agreement as to how to end the conflict" (Bell and Badanjak 2019, p. 453).

All peace agreements in the UCDP PA-D received codes for peace process, according to information collected and updated in the UCDP Conflict Encyclopedia (UCDP database). Three hundred fifty five peace agreements are associated with 142 peace processes, a ratio of 2.5 agreements per peace process. However, there are peace processes with just one agreement, such as the 2018 process between the government of Ethiopia and the Ogaden National Liberation Front (process No. 142) and processes with more than 10 agreements, such as the 2002-2005 peace process between the government of Sudan and the Sudan People's Liberation Movement (process No. 62), in which after 13 partial agreements, a full peace 
agreement was reached in 2005. There are also peace processes with long breaks between agreements, such as a peace process between Eritrea and Ethiopia (process No. 66) in which two peace agreements from the year 2000 and two from 2018 are coded as belonging to the same peace process.

All peace agreements in the PA-X are coded for peace processes according to information collected from country-specific websites and literature. In all, 1832 peace agreements are associated with 158 peace processes, a ratio of 11 agreements per process. This ratio is much higher than the UCDP PA-D of 2.5 agreements per peace process. These data raise questions about why the average number of agreements per peace process differs so dramatically? One possible answer is that PA-X defines agreement more broadly and, thus, includes more documents as such than the UCDP PA-D. For instance, the Trilateral Statement on the Middle East Summit at Camp David (Camp David II) is an agreement included in PA-X but not in UCDP PA-D

\section{Inconsistencies Associating Agreements with Processes within each Dataset}

Identifying the point at which a peace process begins and ends is often tricky because both datasets also have internal inconsistencies in sorting agreements with processes. For example, Table 1a contains some UCDP variables of the conflict 'Israel: Palestine' (conflict No. 234), showing nine peace agreements, starting with the 'Oslo Agreement' in 1993 and ending with the 'Annapolis Conference Joint Understanding on Negotiations' in 2007. The nine peace agreements are associated with four peace processes (\# 50, 51, 52, 92). Peace Process No. 50 includes four peace agreements, the centre of which is the Oslo I Agreement. Peace Process No. 51 includes the Oslo II Agreement and the Hebron Agreement. However, if we use UCDP's own definition of peace process, Oslo II is a direct continuation of Oslo I, so there is no reason to separate them into two peace processes. Additionally, the 'framework' variable is coded as ' 1 ' for all four agreements in process No. 50 (all nine, in fact, have this coding), which means these agreements were signed as part of an ongoing process and not as the final agreement ending a process. Since these agreements were still in force when the Oslo II Agreement was signed between the same signatories, the expectation is that the Oslo II agreement would be a continuation of the same process (No. 50) and not as a beginning of a new process (No. 51) as it is actually coded.

Moreover, peace process No. 52 includes the Wye Memorandum and the Sharm El-Sheikh Memorandum, however I cannot think of a reason to lump them 
Table 1a: Israel: Palestine at the UCDP PA-D.

\begin{tabular}{|c|c|c|c|c|}
\hline Conflict & Date & Process & Agreement & Frame \\
\hline Israel: Palestine & 1993 & 50 & $\begin{array}{l}\text { Declaration of rind pies on } \\
\text { interim self-government } \\
\text { arrangements/Oslo agreement }\end{array}$ & 1 \\
\hline Israel: Palestine & 1994 & 50 & $\begin{array}{l}\text { Agreement on the Gaza strip } \\
\text { and the Jericho area }\end{array}$ & 1 \\
\hline Israel: Palestine & 1994 & 50 & $\begin{array}{l}\text { Agreement on reparatory } \\
\text { transfer of powers and } \\
\text { responsibilities between Israel } \\
\text { and the PLO }\end{array}$ & 1 \\
\hline Israel: Palestine & 1995 & 50 & $\begin{array}{l}\text { Protocol on further transfer of } \\
\text { powers and } \\
\text { responsibilities }\end{array}$ & 1 \\
\hline Israel: Palestine & 1995 & 51 & $\begin{array}{l}\text { Israeli-Palestinian interim } \\
\text { agreement on the } \\
\text { West Bank and the Gaza strip/ } \\
\text { Oslo II }\end{array}$ & 1 \\
\hline Israel: Palestine & 1997 & 51 & $\begin{array}{l}\text { Protocol on redeployment in } \\
\text { Hebron }\end{array}$ & 1 \\
\hline Israel: Palestine & 1998 & 52 & The wye river memorandum & 1 \\
\hline Israel: Palestine & 1999 & 52 & $\begin{array}{l}\text { The Sharm el-Sheik memoran- } \\
\text { dum wye II }\end{array}$ & 1 \\
\hline Israel: Palestine & 2007 & 92 & $\begin{array}{l}\text { Annapolis conference joint un- } \\
\text { derstanding on negotiations }\end{array}$ & 1 \\
\hline
\end{tabular}

together, separate from the rest, when each agreement was signed by a different prime minister of Israel. Peace Process No. 92 includes the Annapolis Conference. This agreement is separated from previous agreements that collapsed after the failure of the July 2000 Camp David Conference and the outbreak of the Al-Aqsa Intifada in September 2000. Therefore, in the Israel/Palestine case, and according to the UCDP definition of peace process, the eight agreements signed until 2000 when the Oslo process collapsed, and the al-Aqsa Intifada broke out, should be included in one peace process. Another optional division may be in accordance with the time when Israeli Prime Minister Yitzhak Rabin was assassinated, November 1995, which many consider an end to the peace process.

Deciding which agreement is the beginning of a process and which agreement is the end of a process is complicated and we have no established criteria for such coding. The UCDP PA-D's definition of a peace process raises questions reflected in many cases. For instance, the two peace agreements between Ethiopia and Eritrea 
signed in 2018 might be considered a continuation of the two agreements signed between them in 2000? If, for example, the 2018 agreements mention the agreements from 2000, then it might meet the definition for continuity. Following this same logic, peace agreements between the government of Colombia and the FARC signed between 1999 and 2002 should be included in the same peace process as the agreements signed in 2012-2016 between the same parties. However, in practice, the UCDP PA-D associates the agreements with different peace processes. In the case of Colombia, coding a negotiation that began in 2012 as a different process than one that began in 1999 stems from a change in leadership and because the agreements between 2012 and 2016 succeeded in reaching an end to the conflict while the agreements between 1999 and 2002 failed. Moreover, according to the UCDP PA-D, even the eight agreements signed between 2012 and 2016 are not associated with the same process but with two different processes (No's. 111 and 112). It is the case that all the agreements are related for they all address in one way or another the same protracted conflict; the problem is coding them according to ambiguous definitions that include vague language like "agreements built on previous peace agreements ..." belong to the same process. What does "built on" mean? Without operationalizing the core concepts of this field, the coding is unreliable across data production endeavors.

As with UCDP PA-D, the point at which a peace process begins and ends is also ambiguous with the PA-X Dataset. For example, if we examine the IsraeliPalestinian conflict, as seen in Table 1b, all 33 agreements between Israelis and Palestinians are coded by PA-X as one peace process: "the Israeli-Palestinian peace process”, No. 63. However, some might argue that after the Camp David conference failed and the Al-Aqsa Intifada broke out in 2000, any renewed contact between the parties could be considered a new peace process. Another dispute regards the decision to include the 2012 ceasefire agreement between Israel and Hamas as part of the Israeli-Palestinian peace process. After all, there is a big difference between an agreement that promotes a peace process and an agreement that promotes a ceasefire. Also, the party that signed the agreement is not Fatah or the Palestinian Authority, as in previous agreements, but Hamas, which is not recognized as legitimate by Israel.

Another wonder is the decision to include the Treaty of Peace between the State of Israel and the Hashemite Kingdom of Jordan as part of the IsraeliPalestinian peace process. Of course, the cases are related, which PA-X indicates by naming the agreements as Israel-Jordan (Palestine) conflict. However, the agreements between Israel and Jordan should be associated with a separate peace process from the agreements between Israel and the PLO because a peace process is defined as an attempt to bring political and/or military protagonists of conflict to 
Table 1b: Israel/Palestine at the PA-X.

\begin{tabular}{|c|c|c|c|c|}
\hline Conflict & Date & Process & Agreement & Stage \\
\hline $\begin{array}{l}\text { Israel/ } \\
\text { (Palestine) }\end{array}$ & 1991 & 63 & $\begin{array}{l}\text { Letter of invitation to Madrid peace } \\
\text { conference }\end{array}$ & Pre \\
\hline $\begin{array}{l}\text { Israel/ } \\
\text { Palestine }\end{array}$ & 1991 & 63 & $\begin{array}{l}\text { Israel/PLO recognition - exchange of } \\
\text { letters }\end{array}$ & Pre \\
\hline $\begin{array}{l}\text { Israel/ } \\
\text { Palestine }\end{array}$ & 1993 & 63 & $\begin{array}{l}\text { Declaration of principles on interim } \\
\text { self-government arrangements ('Oslo } \\
\text { Accords') }\end{array}$ & SubPar \\
\hline $\begin{array}{l}\text { Israel/Jordan/ } \\
\text { (Palestine) }\end{array}$ & 1993 & 63 & Agreed common agenda & Pre \\
\hline $\begin{array}{l}\text { Israel/ } \\
\text { Palestine }\end{array}$ & 1994 & 63 & $\begin{array}{l}\text { Agreement on the Gaza strip and the } \\
\text { Jericho area ('Cairo Agreement') }\end{array}$ & SubPar \\
\hline $\begin{array}{l}\text { Israel/ } \\
\text { Palestine }\end{array}$ & 1994 & 63 & $\begin{array}{l}\text { Agreement on preparatory transfer of } \\
\text { powers and responsibilities }\end{array}$ & $\operatorname{Imp}$ \\
\hline $\begin{array}{l}\text { Israel/Jordan/ } \\
\text { (Palestine) }\end{array}$ & 1994 & 63 & $\begin{array}{l}\text { Treaty of peace between the sate of } \\
\text { Israel and the Hashemite Kingdom of } \\
\text { Jordan }\end{array}$ & SubComp \\
\hline $\begin{array}{l}\text { Israel/Jordan/ } \\
\text { (Palestine) }\end{array}$ & 1994 & 63 & The Washington declaration & Pre \\
\hline $\begin{array}{l}\text { Israel/ } \\
\text { Palestine }\end{array}$ & 1994 & 63 & $\begin{array}{l}\text { Letters exchanges between PLO Chair- } \\
\text { men Yasser Arafat and Israeli Prime } \\
\text { Minister M }\end{array}$ & SubPar \\
\hline $\begin{array}{l}\text { Israel/ } \\
\text { Palestine }\end{array}$ & 1994 & 63 & Protocol on economic relations & Pre \\
\hline $\begin{array}{l}\text { Israel/ } \\
\text { Palestine }\end{array}$ & 1995 & 63 & $\begin{array}{l}\text { Israeli-Palestinian interim agreement } \\
\text { on the West Bank and the Gaza strip } \\
\text { ('Oslo II') }\end{array}$ & SubPar \\
\hline $\begin{array}{l}\text { Israel/ } \\
\text { Palestine }\end{array}$ & 1995 & 63 & $\begin{array}{l}\text { Protocol on further transfer of powers } \\
\text { and responsibilities }\end{array}$ & SubPar \\
\hline $\begin{array}{l}\text { Israel/ } \\
\text { Palestine }\end{array}$ & 1995 & 63 & $\begin{array}{l}\text { Annex I, protocol concerning rede- } \\
\text { ployment and security arrangements } \\
\text { (Oslo II) }\end{array}$ & SubPar \\
\hline $\begin{array}{l}\text { Israel/ } \\
\text { Palestine }\end{array}$ & 1995 & 63 & $\begin{array}{l}\text { Annex II, protocol concerning elections } \\
\text { (Oslo II) }\end{array}$ & SubPar \\
\hline $\begin{array}{l}\text { Israel/ } \\
\text { Palestine }\end{array}$ & 1995 & 63 & $\begin{array}{l}\text { Annex III, Concerning Civil Affairs } \\
\text { (Oslo II) }\end{array}$ & SubPar \\
\hline $\begin{array}{l}\text { Israel/ } \\
\text { Palestine }\end{array}$ & 1995 & 63 & $\begin{array}{l}\text { Annex IV, protocol concerning legal } \\
\text { affairs (Oslo II) }\end{array}$ & SubPar \\
\hline $\begin{array}{l}\text { Israel/ } \\
\text { Palestine }\end{array}$ & 1995 & 63 & $\begin{array}{l}\text { Annex V, protocol on economic re- } \\
\text { lations (Oslo II) }\end{array}$ & SubPar \\
\hline $\begin{array}{l}\text { Israel/ } \\
\text { Palestine }\end{array}$ & 1995 & 63 & $\begin{array}{l}\text { Annex VI, protocol concerning Israeli- } \\
\text { Palestinian cooperation programs } \\
\text { (Oslo II) }\end{array}$ & SubPar \\
\hline
\end{tabular}


Table 1b: (continued)

\begin{tabular}{|c|c|c|c|c|}
\hline Conflict & Date & Process & Agreement & Stage \\
\hline $\begin{array}{l}\text { Israel/ } \\
\text { Palestine }\end{array}$ & 1995 & 63 & $\begin{array}{l}\text { Annex VII, release of Palestinian pris- } \\
\text { oners and detainees (Oslo II) }\end{array}$ & SubPar \\
\hline $\begin{array}{l}\text { Israel/Jordan/ } \\
\text { (Palestine) }\end{array}$ & 1996 & 63 & $\begin{array}{l}\text { Declaration on cooperation on water- } \\
\text { related matters }\end{array}$ & SubPar \\
\hline $\begin{array}{l}\text { Israel/ } \\
\text { Palestine }\end{array}$ & 1996 & 63 & $\begin{array}{l}\text { Agreement on the temporary interna- } \\
\text { tional presence in the City of Hebron }\end{array}$ & SubPar \\
\hline $\begin{array}{l}\text { Israel/ } \\
\text { Palestine }\end{array}$ & 1997 & 63 & $\begin{array}{l}\text { Protocol concerning the redeployment } \\
\text { in Hebron }\end{array}$ & Imp \\
\hline $\begin{array}{l}\text { Israel/ } \\
\text { Palestine }\end{array}$ & 1997 & 63 & $\begin{array}{l}\text { Agreement on temporary international } \\
\text { presence in the City of Hebron (II) }\end{array}$ & Imp \\
\hline $\begin{array}{l}\text { Israel/ } \\
\text { Palestine }\end{array}$ & 1997 & 63 & Note for the record & Imp \\
\hline $\begin{array}{l}\text { Israel/ } \\
\text { Palestine }\end{array}$ & 1998 & 63 & Wye river memorandum & Imp \\
\hline $\begin{array}{l}\text { Israel/ } \\
\text { Palestine }\end{array}$ & 1999 & 63 & Sharm El Sheikh memorandum & Imp \\
\hline $\begin{array}{l}\text { Israel/ } \\
\text { Palestine }\end{array}$ & 1999 & 63 & $\begin{array}{l}\text { Protocol concerning safe passage be- } \\
\text { tween the West Bank and the Gaza } \\
\text { strip }\end{array}$ & Imp \\
\hline $\begin{array}{l}\text { Israel/ } \\
\text { Palestine }\end{array}$ & 2000 & 63 & $\begin{array}{l}\text { Trilateral statement on the Middle East } \\
\text { summit at Camp David (Camp David II) }\end{array}$ & Pre \\
\hline $\begin{array}{l}\text { Israel/ } \\
\text { Palestine }\end{array}$ & 2003 & 63 & $\begin{array}{l}\text { A performance based roadmap to a } \\
\text { permanent two-state solution }\end{array}$ & Pre \\
\hline $\begin{array}{l}\text { Israel/ } \\
\text { Palestine }\end{array}$ & 2005 & 63 & Agreed principles for Rafah crossing & SubPar \\
\hline $\begin{array}{l}\text { Israel/ } \\
\text { Palestine }\end{array}$ & 2005 & 63 & Agreement on movement and access & SubPar \\
\hline $\begin{array}{l}\text { Israel/ } \\
\text { Palestine }\end{array}$ & 2007 & 63 & $\begin{array}{l}\text { Annapolis conference joint under- } \\
\text { standing on negotiations }\end{array}$ & Pre \\
\hline $\begin{array}{l}\text { Israel/ } \\
\text { Palestine }\end{array}$ & 2012 & 63 & $\begin{array}{l}\text { Understanding regarding ceasefire in } \\
\text { Gaza strip }\end{array}$ & Cea \\
\hline
\end{tabular}

end the conflict. Again, upon what criteria are we defining categories and aggregating agreements to processes?

The definition of peace process in PA-X is broad. Not unlike the 33 agreements that make up the Israel-Palestine process, in Burundi there are 22 peace agreements between the government and various rebel groups associated with process No. 16, named 'Arusha and related peace process'. It is accurate that all agreements are indeed related to the 2000 Arusha agreement in one way or another; however, the Arusha agreement was not signed by two main rebel groups: CNDD-FDD and 
Palipehutu-FNL. In 2003, the main group CNDD-FDD began negotiating with the government and signed four agreements that resulted in a comprehensive agreement ('The Global ceasefire agreement between the Transitional Government and the CNDD-FDD of Mr. Nkúrunziza') which ended the conflict between the government and the CNDD-FDD. However, it was not until 18 June 2006 that an initial agreement was signed between the government and the Palipehutu-FNL. After several rounds of negotiations and agreements, on 4 December 2008, the parties signed the comprehensive peace agreement ('Declaration of the Summit of the Heads of State and Government of the Great Lakes region on the Burundi Peace Process') that ended the conflict between the government and the Palipehutu-FNL.

Thus, while all agreements do in fact relate to the Arusha agreement, in practice there are at least three separate peace processes each of which culminated in a comprehensive agreement that ended the conflict between the government and one of the factions. And, crucially, each process comprises myriad related peace agreements. For example, once the June 18, 2006 'Dar-es-Salaam Agreement on Principles Towards Lasting Peace, Security, and Stability in Burundi' was signed, all agreements between the government and the Palipehutu-FNL take this agreement as the starting point of the process until the final agreement.

Another example comes from Uganda. From 1998 a dialogue was held between the government and UNRF II, and in 2002 the parties signed the comprehensive Yumbe peace agreement, after which the UNRF II disarmed and the conflict ended. This agreement is coded as belonging to peace process No. 120. However, other agreements signed in 2007-2008 between the government of Uganda and the LRA are also associated with this same peace process. The initiative for the 2007-2008 agreements began in 2006 with 'the Juba process,' a separate process with different actors than the one from 1998 to 2002. So, the question remains according to what criteria are agreements sorted into processes?

\section{Aggregating Data from Agreements to Processes}

The inconsistencies of associating agreements with processes both within and between the two datasets raises difficulties in obtaining reliable data regarding agreed upon issues in any peace process. I will show the difficulties with data reliability between the two datasets using two negotiated issues of long-term significance far beyond a single signed agreement and, therefore, suitable to be examined in a peace process. The issues are truth and reconciliation. In Truth, the intention is to agree on mechanisms to investigate the wrongs that occurred during 
the conflict and in reconciliation the intention to agree on mechanisms for dialogue and the healing of the conflicting societies. In this section, I will first discuss the way in which truth and reconciliation appear in peace agreements, as well as the way to codify only the places when there is a commitment to actions to achieve truth or reconciliation. I will then show how agreement-level data are grouped into a process-level in each of the datasets, thereby highlighting the difference in the data obtained.

\subsection{Truth and Reconciliation}

Searching for the "truth" about the conflict requires exploring its history. In most cases, each party has its own "truth" which contradicts the other party's truth and usually sees the other side as threatening and scary. This may be one of the reasons for the continuation and establishment of the conflict between the parties, or the so-called historical narrative of the conflict (Bashir 2011). Moreover, each side of the conflict, and especially the more dominant one, works to hide the wrongs it committed. An investigation into the history of the conflict, as well as the disclosure of history, may be undertaken in a number of ways, such as hearing testimony from victims, confession of wrongdoers, and establishing committees to investigate historical wrongs and publish reports that reveal the results of the investigation, or 'truth commissions' (Hayner 2010).

In coding for language that indicates a provision of 'truth' in peace agreements, it is not enough to simply identify general statements about the importance of the truth. There must be a commitment to provide for a body to investigate the past. In other words, there must be a substantial commitment to adopt a mechanism for the investigation of truth and dealing with the past, such as a timetable for the operation of such a body, a date for its establishment, its participants, etc.

An example of language indicating the provision of truth can be seen in the peace process in Mali (Pacte National agreement), which contains a substantive commitment to a creation of an independent commission of enquiry within 15 days after the signature of the pact. Section 14 details the mandate of the commission:

The Independent Commission of Enquiry will enquire into all the events which have taken place in Mali with relation to the problems of the North, specifically: crimes committed against the civil populations in their physical and moral persons as well as their properties, violations of the environment and destruction of livestock, theft, pillage and every act of vandalism and damage. The Commission will work to define the responsibility for such acts, their consequences, to evaluate the damages and compensations due to victims (Pacte National Agreement, 1992, article 14). 
Another example can be seen in the El Salvadorian peace process (the Mexico Agreement), which contains a commitment to create a truth commission:

Commission on the Truth: Agreement has been reached to establish a Commission on the truth ... The Commission shall be entrusted with the task of investigating serious acts of violence that have occurred since 1980 and whose impact on society urgently requires that the public should know the truth ... (Mexico Agreement, 1991, article IV).

The concept of reconciliation is sometimes amorphous. What is meant by reconciliation is that the interaction between former opponents undergoes a transformation, focusing on "devastating perceptions and behaviours toward the other side of the conflict, toward constructive relationships and lasting peace" (Brounéus 2003, p. 3). A reconciliation process creates and consolidates the relationship between the disputed parties, a transformation of attitudes and feelings of the parties towards each other and its conflict and history (Bar-Tal 2000; Govier and Prager 2003; Skaar 2013). Although reconciliation does not guarantee that there will be no future disagreements between the parties, "it assures that the relationship will not return to the situation where the existential legitimacy of each party is challenged" (Rouhana 2011, p. 296).

In coding for language that indicates the provision of 'reconciliation' in peace agreements, as in coding for 'truth', it is not enough to find general statements about the importance of reconciliation. There needs to be a substantive commitment for actions aimed at reconciliation. For example, committees to reach dialog, healing, and reconciliation between disputed groups or societies. There must be a substantial commitment to adopt a mechanism for achieving reconciliation.

An example of the language used for reconciliation can be seen in the peace process in Tajikistan between the government and the United Tajik Opposition (UTO). In February 2007 the parties signed 'the Statute of the Commission on National Reconciliation', which establishes a commission on national reconciliation, providing its composition, main functions and timeframe:

2. The purview of the Commission includes the whole range of problems associated with national reconciliation. Its tasks shall be to implement the agreements reached in the course of the inter-Tajik talks, to promote the creation of an atmosphere of trust and mutual forgiveness and to institute a broad dialogue among the various political forces in the country with a view to restoring and strengthening civil accord in Tajikistan.

3. The Commission is a temporary body, established for the transition period. It shall cease its activity after the convening of the new Parliament and the formation of its leadership structures. The Commission on National Reconciliation shall begin its work two weeks after the signing of the Protocols on military and political issues (The Statute of the Commission on National Reconciliation 2007). 
Another example can be seen in the Bougainville Peace Agreement between the government of Papua New Guinea and the Bougainville Revolutionary Army (BRA). In August 2001, the parties signed the Bougainville Peace Agreement. Under the title 'reconciliation, and unified structures for Bougainville', several articles detail the importance of reconciliation:

338. The success of the peace process has been based on resolution of tensions and differences through a wide range of reconciliation efforts. 339. Reconciliation has many aspects, including customary, religious, spiritual, personal, psychological, and economic. It includes concerns for history, memory and justice. These qualities have been evident in the many reconciliation efforts made in Bougainville, within and between families and communities. For the peace to be self-sustaining, reconciliation efforts must continue. [...] 341. The signing of this Agreement is intended to be a symbol of progress in reconciliation. 342. The parties commit themselves to continuing to promote and pursue meaningful reconciliation both within Bougainville and between Bougainville and the rest of Papua New Guinea (Bougainville Peace Agreement, 2001, pp.70-71).

To make sure my coding is reliable, I compared it with UCDP PA-D and PA-X coding. UCDP PA-D coded reconciliation if "the agreement included the concept of National Reconciliation” (Högbladh 2019, p. 7). PA-X coded reconciliation in three levels, with the second and third levels about "provisions going beyond a mere 'call' for reconciliation to establish some sort of reconciliation measure or activity in its own right” (Bell et al. 2020, p. 68). The second and third levels meet the language criteria for indicating the provision of 'reconciliation' I look for in my study, therefore, I estimate my coding is reliable when coded at these levels at PA-X. The UCDP PA-D does not code for truth, while the PA-X codes for truth at three levels with the second and third levels containing substantive commitment to adopt the mechanism to deal with the past. Here, too, the second and third levels meet the language criteria indicating the provision of 'truth' I look for in my study, therefore, I estimate my coding is reliable where it was coded at these levels at PA-X.

\subsection{Aggregating Provisions from Agreements to Processes}

For the aggregating and comparison, I used only agreements included in both UCDP PA-D and PA-X, a total of 314 agreements between 1990 and 2018. In the conflict of Liberia, for example, PA-X has 29 agreements and UCDP PA-D has 13 agreements. All 13 agreements of UCDP PA-D are also included in PA-X, so I use 
those 13 for aggregating agreements with processes. The conflict in Liberia, as mentioned earlier, included two civil wars, the first between 1989 and 1997, and the second between 1999 and 2003. The first agreement included in both UCDP PA-D and PA-X is Banjul III Agreement signed in 1990 between the government and the INPFL. As is seen in Table 2a, this agreement is associated in PA-X with process No. 69 and in UCDP PA-D with process No. 27. The other 12 agreements in PA-X are associated with process No. 69. However, in UCDP PA-D they are associated with three more processes: Bamako, Nanjul IV and Lomé agreements signed in 1990-1991 between the government and both INPFL and NPFL, are associated with process No. 28; seven other agreements that were signed in 1991-1996 between the government and NPFL, are associated with process No. 29; and two agreements signed in 2003 between the government and both MODEL and LURD, are associated with process No. 30 .

Table 2a: Liberia_Coding truth and reconciliation provisions in agreements and associating agreements with processes.

\begin{tabular}{|c|c|c|c|c|c|c|}
\hline Conflict & Peace agreement & pa_date & Truth & Reconciliation & $\begin{array}{r}\text { Process } \\
\text { UCDP }\end{array}$ & $\begin{array}{r}\text { Process } \\
\text { PAX }\end{array}$ \\
\hline Liberia & Banjul III agreement & $1990-10-24$ & 0 & 0 & 27 & 69 \\
\hline \multirow[t]{12}{*}{ (Government) } & $\begin{array}{l}\text { Bamako ceasefire } \\
\text { agreement }\end{array}$ & $1990-11-28$ & 0 & 0 & 28 & \\
\hline & Banjul IV agreement & $1990-12-21$ & 0 & 0 & & \\
\hline & $\begin{array}{l}\text { Lomé ceasefire } \\
\text { agreement }\end{array}$ & $1991-02-13$ & 0 & 0 & & \\
\hline & $\begin{array}{l}\text { Yamossoukro IV } \\
\text { agreement }\end{array}$ & $1991-10-30$ & 0 & 0 & 29 & \\
\hline & Geneva agreement & 1992-04-07 & 0 & 0 & & \\
\hline & Cotonou agreement & $1993-07-25$ & 0 & 0 & & \\
\hline & Akosombo agreement & $1994-09-12$ & 0 & 0 & & \\
\hline & $\begin{array}{l}\text { Clarification of the } \\
\text { Akosombo agrmt }\end{array}$ & $1994-12-21$ & 0 & 0 & & \\
\hline & $\begin{array}{l}\text { Abuja peace } \\
\text { agreement }\end{array}$ & $1995-08-19$ & 0 & 0 & & \\
\hline & $\begin{array}{l}\text { Supplement to the } \\
\text { Abuja accord }\end{array}$ & $1996-08-17$ & 0 & 0 & & \\
\hline & $\begin{array}{l}\text { Accra ceasefire } \\
\text { agreement }\end{array}$ & $2003-06-17$ & 0 & 0 & 30 & \\
\hline & $\begin{array}{l}\text { Accra comprehensive } \\
\text { agreement }\end{array}$ & 2003-08-18 & 1 & 1 & & \\
\hline
\end{tabular}


After assigning peace agreements with a peace process, I suggest treating them as one text. I examine whether provisions of truth and reconciliation are included in the text of the agreements assigned to each peace process, and accordingly each provision is coded as $1 / 0$. Therefore, when truth or reconciliation is identified in one or more of the agreements associated with a peace process, I code the entire peace process as having this component. In Liberia, from all 13 agreements, the only one that included the provisions of truth and reconciliation is the Accra Comprehensive Agreement (as is seen in Table 2a).

In the aggregating process using the UCDP PA-D assigning of agreements to processes, the Accra Agreement is associated with process No. 30, so this process was coded as including the provisions of truth and reconciliation. As is seen in Table 2b, the other three processes - Nos. 27, 28 and 29 - were coded as not including truth and reconciliation. So out of four peace processes related with the Liberian conflict, only one includes these provisions, namely $1 / 4$ or 25 percent. In contrast, using the PA-X assigning of agreements to processes, the Accra Agreement is associated with process No. 69 , so this process was coded as including the provisions of truth and reconciliation. So, the one peace process related to the Liberian conflict includes these provisions, namely $1 / 1$ or 100 percent.

With respect to the 314 agreements included in both UCDP and PA-X, the association of agreements to processes, in UCDP the 314 agreements are associated with 108 processes, and in PA-X with 70 processes. The data show that $42 \%$ from the peace processes in PA-X include provisions of reconciliation, in contrast to $31 \%$ from the peace process in UCDP. In addition, $27 \%$ from the peace processes in PA-X include provisions of truth, while $24 \%$ from the peace process in UCDP (see Figure 1).

Table 2b: Liberia_Data on truth and reconciliation provisions in peace processes.

\begin{tabular}{lrrlrr}
\hline UCDP proc & Truth & Recon & PA-X proc & Truth & Recon \\
\hline Liberian peace process 1 (No. 27) (1990) & 0 & 0 & Liberian peace & 1 & 1 \\
Liberian peace process 2 (No. 28) (1990-1991) & 0 & 0 & process (No. 69) & & \\
Liberian peace process 3 (No. 29) (1991-1996) & 0 & 0 & & & \\
Liberian peace process 4 (No. 30) (2003) & 1 & 1 & & & \\
\hline
\end{tabular}

As can be seen in Appendix I, in a comparison between the two datasets, out of 63 conflicts 30 include peace agreements associated differently with peace processes while 33 associated similarly. The 30 conflicts in which peace agreements 
are associated differently with peace processes in UCDP PA-D compared to PA-X are presented in Appendix II.

In UCDP PA-D, the agreements in these 30 conflicts are associated with 64 peace processes. In PA-X, the agreements in these 30 conflicts are associated with 27 peace processes. As in the mentioned conflict in Liberia, agreements at the UCDP PA-D are associated with four processes while at the PA-X they are associated with one process. And as stated above, only one from four process at UCDP PA-D includes truth and reconciliation provisions (25\%), while one from one process at PA-X includes these provisions (100\%). The data as in the case of Liberia are an example of the difference in all other such processes: 59\% of peace processes in PA-X included provisions of reconciliation, in contrast to $31 \%$ of peace processes in UCDP PA-D; 44\% of peace processes in PA-X included provisions of truth, in contrast to $30 \%$ of peace processes in UCDP PA-D. Thus, the provision of reconciliation in PA-X is almost two times than that of UCDP PA-D, and the provision of truth in PA-X is 1.5 times than in UCDP.

The 33 conflicts in which peace agreements are associated similarly with peace processes in UCDP PA-D compared to PA-X are presented in Appendix II. The agreements in these 33 conflicts are associated similarly with 43 peace processes at both UCDP PA-D and PA-X. As an example, all agreements in the peace process in Anjouan between the government of Comoros and the Popular Movement of Anjouan (MPA), are associated similarly in both UCDP PA-D and PA-X (as is seen in Table 3a).

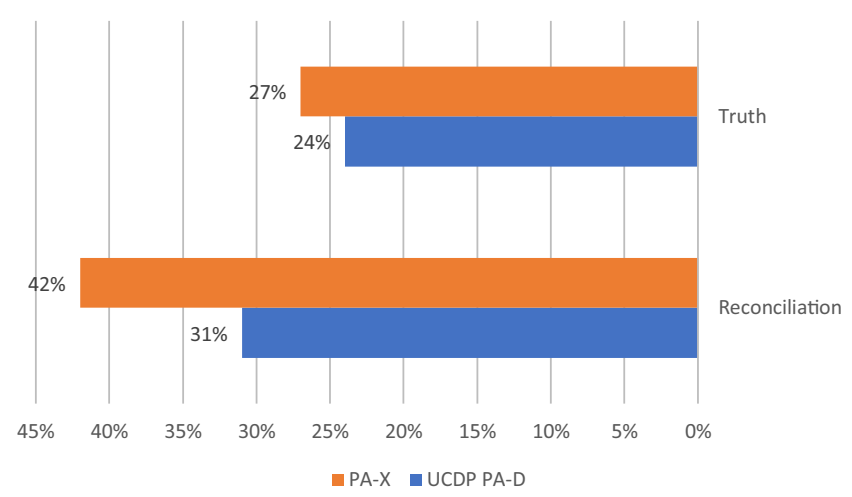

Figure 1: Rates of provisions on truth and reconciliation from all peace processes in each dataset. 
Table 3a: Comoros: Anjouan_Coding truth and reconciliation provisions in agreements and associating agreements with processes.

\begin{tabular}{|c|c|c|c|c|c|c|}
\hline Conflict & Peace agreement & pa_date & Truth & Reconciliation & $\begin{array}{r}\text { Process } \\
\text { UCDP }\end{array}$ & $\begin{array}{r}\text { Process } \\
\text { PAX }\end{array}$ \\
\hline \multirow[t]{4}{*}{$\begin{array}{l}\text { Comoros: } \\
\text { Anjouan }\end{array}$} & $\begin{array}{l}\text { Addis Ababa } \\
\text { agreement }\end{array}$ & $1997-12-13$ & 0 & 0 & 44 & 15 \\
\hline & $\begin{array}{l}\text { The Farmboni } \\
\text { declaration }\end{array}$ & $2000-08-26$ & 0 & 0 & & \\
\hline & $\begin{array}{l}\text { The Farmboni II } \\
\text { agreement }\end{array}$ & $2001-02-17$ & 0 & 1 & & \\
\hline & $\begin{array}{l}\text { Agrmts on the transi- } \\
\text { tional arrangements }\end{array}$ & $2003-12-20$ & 0 & 0 & & \\
\hline
\end{tabular}

In the aggregating of agreements to processes, because that the Famboni II agreement included a provision of reconciliation, both processes (No. 44 in UCDP PA-D and No. 15 in PA-X) are coded as including the provision of reconciliation, as seen in Table 3b.

Table 3b: Comoros: Anjouan_Data on truth and reconciliation provisions in peace processes.

\begin{tabular}{|c|c|c|c|c|c|}
\hline UCDP process & Truth & Reconciliation & PAX process & Truth & Reconciliation \\
\hline $\begin{array}{l}\text { Anjouan peace process } \\
\text { (No. 0.44) (1997-2003) }\end{array}$ & 0 & 1 & $\begin{array}{l}\text { Anjouan peace process } \\
\text { (No. 15) (1997-2003) }\end{array}$ & 0 & 1 \\
\hline
\end{tabular}

The data from both datasets is the same: $30 \%$ of peace processes included provisions of reconciliation, and $16 \%$ included provisions of truth.

In conclusion, the UCDP PA-D and PA-X have groups of agreements associated with the same peace processes, as is the case with Anjouan, and have groups of agreements associated with different peace processes, as is the case with Liberia. These differences affect how data are aggregated from the peace agreement level to the peace process level.

\section{Suggesting Preliminary Options for Sorting Agreements into Processes}

In light of the differences between and the inconsistencies within the databases and the absence of clear definitions to guide our coding practices, below I consider some possible approaches when working with these kinds of data. 
a) One option is to lump all agreements signed within an armed conflict into one peace process regardless of: the duration of the armed conflict, the signatories to the agreements, or whether the conflict ended or resumed. In such a case, one would rely on a database of armed conflicts, gather all the agreements associated with the conflict to then aggregate to the level of peace processes. This method for associating agreements with processes is more readily reflected in PA-X than in UCDP PA-D. For example, while in UCDP PA-D, the 16 peace agreements in the Burundi conflict are associated with four peace processes, in PA-X all 16 agreements are associated with just one. Another example can be taken from the Azawad region in northern Mali. Three agreements were signed in 1991-1992 between the government of Mali, the MPA (Popular Movement for the Liberation of Azawad), and other rebel groups. The final agreement, 'Pacte National', lasted until 1994 when the FIAA, a signatory of the Pact, declared war on the Malian government (UCDP Encyclopedia). These three agreements of 1991-1992 are associated with one peace process in both datasets (No. 54 in UCDP PA-D, No. 74 in PA-X). In 2012 a new episode of the conflict over Azawad broke out. One agreement was signed in 2013 and two agreements were signed in 2015 between the government and the CMA (Coordination of Azawad Movements). In PA-X, these agreements are associated with the same process as the 1991-1992 agreements (No. 74) while in UCDP PA-D, the three agreements from 2013-2015 are each associated with a different peace process (\#103, 121, 122).

b) Another option is to associate all agreements signed by the same signatory parties to the same peace process. The change in even one signatory party marks the start of a new process and, thus, subsequent agreements will be associated with a new process. The logic of this approach is that when there is a new party in the negotiation, the parties usually start a new process of negotiation on all issues in the conflict. This method is more readily reflected in UCDP PAD than in PA-X. For example, the conflict in Liberia (No. 30) includes two agreements signed in 2003 between the government and both MODEL and LURD. These two agreements ended the second Liberian civil war and, according to the UCDP PA-D, are not related to the previous 11 agreements in Liberia signed between the government and NPFL and INPFL from 1990 to 1996 to settle the first Liberian civil war. Moreover, in 2003 the government was led by Charles Taylor, while in 1990-1996 Taylor led the rebel group NPFL. Therefore, separating the two agreements that ended the second Liberian civil war from the agreements that settled the first civil war seems reasonable. Yet, PA-X codes the two agreements and the 11 other agreements as part of one peace process (No. 69).

However, associating agreements with a new process when a change in the signatory parties occurs is also not straightforward. For example, in cases when a government signs an agreement with one party, and then later signs a similar 
agreement with other parties, is it an entirely new process? As mentioned before, all agreements in the conflict in Burundi are related to the 2000s Arusha peace and reconciliation agreement. The two rebel parties that refused to sign the Arusha agreement, signed later agreements based on what was agreed to in Arusha. An argument can be made for both coding schemes.

c) Another consideration for associating agreements with processes is the agreement's level of comprehensiveness. When an agreement represents a move forward from a period of conflict to a period of post-conflict, this indicates the parties have addressed and resolved conflict incompatibilities, which can signal the end of a process. This method is reflected in cases in both databases.

In UCDP PA-D a comprehensive agreement is defined as a full peace agreement: "an agreement where one or more dyad agrees to settle the whole incompatibility" (Pettersson, Högbladh, and Öberg 2019, p. 590). Such agreements are also called "resolution agreements" in contrast to "intention agreements", in which the parties address part of an incompatibility and express their aim to address the whole incompatibility (Cox 2019, p. 469). In PA-X, agreements that resolve an incompatibility are defined as 'framework-substantive, comprehensive': "agreements that concern parties that are engaged in discussion and agreeing to substantive issues to resolve the conflict and appear to be set out as a comprehensive attempt to resolve" (Bell et al. 2020). When associating agreements with processes, full or substantive-comprehensive agreements mark a resolution of the peace process (including implementation/follow-up agreements). For example, the 'Agreement for a Firm and Lasting Peace' in Guatemala between the government and the URNG is coded as a full agreement by UCDP PA-D and as a substantive-comprehensive agreement by PA-X. This agreement is the last one associated with the peace process (No. 23 [UCDP PA-D] and No. 45 [PA-X]), to which more than 10 previous agreements in Guatemala are associated.

However, in PA-X a substantive-comprehensive agreement is not always used to mark the end of a process and, in many cases, a process includes more than one such agreement, as in the aforementioned process in Burundi (No. 16), which includes five substantive-comprehensive agreements between 2000 and 2008. Furthermore, associating agreements with processes according to the level of incompatibility addressed is ambiguous. First, in some cases, it is difficult to know if all the incompatibility was resolved. Second, all agreements leave some issues for future development. Third, many agreements coded as full in UCDP PA-D are not coded as substantive-comprehensive in PA-X and vice versa. For example, the 'Declaration of the Summit of the Heads of State and Government of the Great Lakes region on the Burundi Peace Process' signed in 2008 is coded as a full agreement in UCDP. According to PA-X this agreement is an implementation agreement of a previous substantive-comprehensive agreement (Agreement on 
Principles Towards lasting Peace, Security, and Stability in Burundi) signed in 2006. In contrast to PA-X, the UCDP PA-D codes this 2006 agreement as a peace process agreement (intention agreement).

In addition, another difficulty concerns coding for partial agreements (intention agreement) as part of a peace process. A partial agreement is an agreement that addresses part of the incompatibility (Pettersson, Högbladh, and Öberg 2019). The logic is that if a partial agreement is signed, the process is not over. And so, the expectation is that the agreement that follows the partial agreement will be associated with the same peace process, as long the parties are the same. For example, when in 2012-2014 the government of the Philippines and the MILF signed several partial agreements all of which are coded as belonging to the same peace process between the same parties in 2005-2006 (No. 59 [UCDP PA-D] and No. 90 [PA-X]). However, there are cases in which although the previous agreement between the parties is defined as partial, the next agreement between the same parties is associated with a new peace process. For example, the partial agreements signed between the government of Colombia and the FARC during 1999 and 2002 are associated with process No. 17 [UCDP PA-D], while agreements between the same parties during 2012 and 2014 are associated with a different process. On the one hand, because 10 years had lapsed since the previous agreement, it makes some sense that a new agreement would indicate the start of a new process. However, in other cases this logic is not maintained, for example, agreements between Eritrea and Ethiopia in 2000 and 2018 are associated with the same process (No. 66).

Yet, there is one differentiation between the case of Colombia-FARC and the case of Philippines-MILF. In Colombia, the agreements in 1999-2002 are coded as 'ended' since the government ended the peace talk after FARC hijacked a plane and kidnaped a senior senator (Forero 2002). In the Philippines, the agreements in 2005-2006 are not coded as 'ended', so this may explain the continuation of the same peace process. However, if the validity of an agreement is key for associating agreements with processes, this is not reflected in other cases. For example, the 'Islamabad accord' signed in 1993 between the government of Afghanistan and the Hizb-i Islami-yi is coded as 'ended', however, the 'Jalalabad accord' signed after the failure of the 'Islamabad accord' is associated with the same peace process (No. 1 [UCDP PA-D]).

d) And, finally, an examination of whether an agreement relies on or mentions a previous agreement is relevant. For example, the government of El Salvador and the FMLN signed the Geneva agreement in April 1990. All subsequent agreements, such as the agreement on Human Rights (San Jose Agreement), mention the April 1990 Geneva Agreement: "[i]n accordance with the provisions of the Geneva Agreement and the agenda for the negotiations which was adopted in Caracas, the Parties 
hereby agree to ...” (Agreement on Human Rights 1990, p. 4). A direct mention of this kind indicates that the 'Agreement on Human Rights' belongs to the same process as the Geneva Agreement (No. 22 [UCDP PA-D], No. 36 [PA-X]).

However, it also makes sense not to associate every agreement that specifies the name of a previous agreement with the same process. For instance, agreements between a government and a rebel group might mention a previous agreement that the government and another rebel group signed. The fact that the name of an agreement is mentioned may not be enough to indicate the agreements are part of the same peace process. Moreover, there are examples of agreements that reference a previous agreement which are associated with yet another agreement not mentioned in the text. As I showed above in the Burundi conflict, although an agreement signed in 2008 mentions an agreement signed in 2006, in PA-X they are both associated with an agreement signed in 2000.

To sum up this section, it is difficult to point to one of the options as the preferred option for associating peace agreements with peace processes because, as noted above, each option has advantages and disadvantages. For those who focus on the armed conflict itself, the first option will likely be most useful because all the agreements in an armed conflict will be associated with the same process. However, for studies that take into account the different parties to an armed conflict, the second option is better because it captures when a change in the signatories occurs and marks that change as the beginning of a new process. Assigning agreements to processes according to agreement type also has advantages especially when processes follow the logic of: preliminary agreement, followed by partial agreements, and ending with a comprehensive agreement. However, conflict and negotiation are not always logical, and agreement-type is often difficult to classify. In these cases, the actual usefulness of this option challenging. Finally, associating an agreement with a process when the agreement relies on/refers to a previous agreement already associated with that process is, indeed, useful when the agreement clearly mentions how it relies on said previous agreement. However, there are multiple and competing motivations for why an agreement might mention a previous one, and so using this option can require more supporting or explanatory evidence.

\section{Summary and Conclusions}

The differences between the datasets and the discrepancies within them affect how data are aggregated from the peace agreement level into the peace process level. While each dataset associates peace agreements with peace processes, they do not offer a way to aggregate data from agreements to the process level. As I have shown 
throughout the study, the aggregation operation takes each group of agreements, treats them as one text, and codes the data on the presence or absence of each provision. The fact that this aggregation cannot be done with the click of a button and during which there are questions like according to what criteria are agreements associate with a process, or how to code a provision that appears in more than one agreement in the same process - explain why there are almost no studies that have done this.

Such complexities in our databases makes characterizing how individual peace agreements are associated with peace processes crucial for reliable and valid findings. Therefore, I recommend developing a disciplinary standard for how such elements ought to be coded which, in turn, will facilitate consistent data production across databases.

Several preliminary approaches for associating agreements with processes are suggested: 1) Same armed-conflicts: all agreements signed within an armed conflict will be assigned to one peace process, regardless of the duration of the armed conflict, the signatories to the agreements, or whether it ended or resumed; 2) Same parties: all agreements signed by the same signatory parties will be assigned to the same peace process; 3) Level of comprehensiveness: when an agreement represents a move forward from conflict into a post-conflict period, this indicates the parties have addressed and resolved conflict incompatibilities, which can signal the end of a process; 4) Reliance on a previous agreement: when an agreement relies on a previous agreement they will be assigned to the same peace process.

These methods for aggregating data are the primary options applied in one way or another in both databases. However, each database approaches these possible coding scenarios differently and both databases apply their own approaches for coding inconsistently. These facts should motivate us to rethink how and according to what principles should we associate peace agreements with peace processes. Establishing clear principles may lead researchers to build a new dataset where peace processes are the primary unit of analysis.

Acknowledgments: I thank the editor in chief and two anonymous reviewers of Peace Economics, Peace Science and Public Policy for their helpful suggestions and careful reading of the article.

\section{References}

Agreement on Human Rights. 1990. Agreement on Human Rights (San Jose Agreement). Also available at https://peacemaker.un.org/sites/peacemaker.un.org/files/SV_900726_

SanjoseAgreement.pdf. 
Badran, R. 2014. “Intrastate Peace Agreements and the Durability of Peace." Conflict Management and Peace Science 31 (2): 193-217.

Bar-Tal, D. 2000. "From Intractable Conflict through Conflict Resolution to Reconciliation: Psychological Analysis.” Political Psychology 21 (2): 351-65.

Bashir, B. 2011. "Reconciling Historical Injustices: Deliberative Democracy and the Politics of Reconciliation.” Res Publica 18 (2): 127-43.

BBC. 2016. "Colombia Peace Deal: Historic Agreement is Signed.” BBC, https://www.bbc.com/ news/world-latin-america-37477202.

Bell, C. 2003. Peace Agreements and Human Rights. New York: Oxford University Press.

Bell, C., and S. Badanjak. 2019. “Introducing PA-X: A New Peace Agreement Database and Dataset." Journal of Peace Research 56 (3): 452-66.

Bell, C., S. Badanjak, J. Beujouan, T. Epple, R. Forster, A. Jamar, S. Molloy, K. McNicholl, K. Nash, P. Jan, R. Wilson, and L. Wise. 2020. PA-X Peace Agreements Database and Dataset, Version 3. Also available at www.peaceagreements.org.

Brounéus, K. 2003. Reconciliation and Development. Berlin: Friedrich-Ebert-Stiftung. Also available at http://library.fes.de/pdf-files/iez/04999.pdf.

Cox, J. M. 2019. "Negotiating Justice: Ceasefires, Peace Agreements, and Post-Conflict Justice." Journal of Peace Research 57: 466-81.

Fontana, G., A. Kartsonaki, N. Neudorfer, D. Walsh, S. Wolff, and C. Yakinthou. 2020. "The Dataset of Political Agreements in Internal Conflicts (PAIC)." Conflict Management and Peace Science. Also available at https://research.birmingham.ac.uk/portal/en/publications/the-datasetof-political-agreements-in-internal-conflicts-paic(573660ad-cc1d-4413-bc06-

2549378ae71b).html?_ga=2.81088020.202491451.1590887898-1526890727.1586769609.

Forero, J. 2002. Colombian Rebels Hijack a Plane and Kidnap a Senator. New-York: The New York Times. https://www.nytimes.com/2002/02/21/world/colombian-rebels-hijack-a-planeand-kidnap-a-senator.html.

Govier, T., and C. A. L. Prager. 2003. Dilemmas of Reconciliation: Cases and Concepts. Waterloo, Ont: Wilfrid Laurier University Press.

Guelke, A. 2014. "Brief Reflections on Measuring Peace." Shared Space 18: 105-12.

Harbom, L., S. Hogbladh, and P. Wallensteen. 2006. "Armed Conflict and Peace Agreements." Journal of Peace Research 43 (5): 617-31.

Hayner, P. B. 2010. Unspeakable Truths: Transitional Justice and the Challenge of Truth Commissions. Routledge.

Högbladh, S. 2012. "Peace Agreements 1975-2011-Updating the UCDP Peace Agreement Dataset." In States in Armed Conflict, edited by L. Themnér, and T. Themnér, 39-56. Uppsala: Uppsala University.

Högbladh, S. 2019. UCDP Peace Agreement Dataset Codebook Version 19.1. Uppsala: Uppsala Conflict Data Program.

Kauffmann, M. 2008. Building and Using Datasets on Armed Conflicts. Amsterdam: IOS Press.

Mallinder, L. 2018. Amnesties and Inclusive Political Settlements (Transitional Justice Series) [PA-X Report]. Global Justice Academy. Edinburgh: University of Edinburgh. Also available at https://www.politicalsettlements.org/publications-database/amnesties-and-inclusivepolitical-settlements/.

McCartney, C., and P. Nolan. 2014. "Tracking Progress in Building Peaceful and Shared Societies." Shared Space 18: 4-12.

Pettersson, T., S. Högbladh, and M. Öberg. 2019. “Organized Violence, 1989-2018 and Peace Agreements." Journal of Peace Research 56 (4): 589-603. 
Rouhana, N. N. 2011. "Key Issues in Reconciliation: Challenging Traditional Assumptions on Conflict Resolution and Power Dynamics." In Intergroup Conflicts and Their Resolution: A Social Psychological Perspective, edited by D. Bar-Tal, 291-314. New-York: Taylor and Francis.

Sambanis, N., and J. Schulhofer-Wohl. 2019. "Sovereignty Rupture as a Central Concept in Quantitative Measures of Civil War." Journal of Conflict Resolution 63 (6): 1542-78.

Skaar, E. 2013. “Reconciliation in a Transitional Justice Perspective." Transitional Justice Review 1 (1): 54-103.

The Statute of the Commission on National Reconciliation. 2007. Also available at https:// peacemaker.un.org/sites/peacemaker.un.org/files/TJ_970221_ StatuteCommissionNationalReconciliation.pdf.

Supplementary Material: The online version of this article offers supplementary material (https:// doi.org/10.1515/peps-2020-0003). 